\title{
Inteligencija, crte ličnosti i profesionalni interesi kao prediktori školskog postignuća
}

\author{
Nada Krapić \\ Odsjek za psihologiju, Filozofski fakultet Sveučilišta u Rijeci, Hrvatska \\ Patricija Kuljanić \\ Odsjek za psihologiju, Filozofski fakultet Sveučilišta u Rijeci, Hrvatska
}

\begin{abstract}
Sažetak
Cilj je provedenog istraživanja bio ispitati u kojoj mjeri inteligencija, crte ličnosti i profesionalni interesi pridonose objašnjenju varijance općega školskog postignuća učenika višeg razreda osnovne škole te postignuća u specifičnim skupinama predmeta (jezično-komunikacijskoj, prirodoslovnoj, društveno-humanističkoj, tehničkoj i umjetničkoj skupini). Pored toga, ispitana je i inkrementalna valjanost crta ličnosti i profesionalnih interesa povrh efekata sposobnosti. U istraživanju je sudjelovalo 263 učenika školskog uzrasta, polaznika osmih razreda jedne riječke osnovne škole, od kojih je 128 ženskog, a 135 muškog spola. Kako bi se ispitala prediktivna snaga inteligencije, crta ličnosti i profesionalnih interesa za predviđanje općega školskog postignuća učenika i postignuća u specifičnim skupinama predmeta kao kriterijskim varijablama, proveden je niz hijerarhijskih regresijskih analiza u kojima je inteligencija uključena u prvom, crte ličnosti u drugom, a profesionalni interesi u trećem koraku. Dobiveni rezultati pokazuju da su verbalne $i$ numeričke sposobnosti, istraživački interesi i savjesnost najvažniji prediktori općega školskog postignuća kao i postignuća u većini specifičnih skupina predmeta pri čemu se količina objašnjene varijance kreće između 9\% i 35\%. Pored toga, pokazalo se da crte ličnosti povrh inteligencije, a profesionalni interesi povrh inteligencije i crta značajno dodatno objašnjavaju varijancu svih kriterijskih varijabli osim uspješnosti u tehničkoj skupini predmeta. Pri tome dimenzije ličnosti i interesi objašnjavaju zajedno u prosjeku još oko $11 \%$ varijance kriterija (ličnost 5\%; profesionalni interesi 6\%). Dobiveni rezultati upućuju na važnost ispitivanih varijabli u razumijevanju i predviđanju osnovnoškolskog postignuća.
\end{abstract}

Ključne riječi: inteligencija, crte ličnosti, profesionalni interesi, školsko postignuće

Nada Krapić, Odsjek za psihologiju, Filozofski fakultet Sveučilišta u Rijeci, Sveučilišna avenija 4, 51000 Rijeka, Hrvatska. E-pošta: nkrapic@ffri.hr

Ovaj je članak nastao u okviru znanstvenog projekta "Ličnost, emocije i socijalni procesi kao odrednice zdravstvenih ishoda (13.04.1.2.01)", koji financira Sveučilište u Rijeci. 


\section{Uvod}

Visoka obrazovna postignuća definiraju se važnim strateškim ciljevima gotovo svake države te je stoga razumljivo sustavno bavljenje istraživača ovom problematikom. U nastojanju da bolje razumiju individualne razlike u tim postignućima znanstvenici su do sada kao njegove temeljne dereminante dijagnosticirali individualna obilježja pojedinca, obilježja njegove obitelji i socijalne okoline te karakteristike škole, nastavnika i nastavnog procesa (Babarović, Burušić i Šakić, 2010), pri čemu se u istraživanjima uobičajeno kao operacionalizacija školske izvedbe koristio školski uspjeh jer predstavlja objektivnu mjeru s dobrom internalnom pouzdanošću i visokom stabilnošću kroz vrijeme. Pored općega školskog uspjeha nerijetko su kao bolja mjera korištene i ocjene iz pojedinačnih predmeta koje određeni broj istraživača smatra adekvatnijim kriterijem postignuća jer osiguravaju manju varijabilnost i veću valjanost ispitivanja (Petska, 2006). Individualna su obilježja pojedinca najčešče istraživana skupina prediktorskih varijabli, a među njima su kao najznačajniji prediktori postignuća u školi utvrđeni inteligencija, crte ličnosti te profesionalni interesi.

Inteligencija, koja se najranije počela ispitivati za predviđanje školskog i akademskog postignuća, sustavno se pokazivala njegovim najboljim samostalnim prediktorom (Laidra, Pullmann i Allik, 2007). Još Jensen (1980) tako navodi da se njezina prediktivna valjanost kreće od .60 do .70 kada govorimo o osnovnoj školi, od .40 do .50 kada govorimo o srednjoj školi te od .30 do .40 kada govorimo o postignuću u visokoškolskom obrazovanju. Jasno da je pad prediktivne valjanosti uzrokovan uzorkom koji je sa starošću sve više selekcioniran. Također, pokazalo se da se korištenjem specifičnih mjera intelektualnih sposobnosti može bolje predvidjeti postignuće u pojedinim školskim predmetima nego što je to moguće mjerom općeg kognitivnog funkcioniranja i općeg školskog uspjeha (Babarović i sur., 2010). Ispitivanja koja su bila fokusirana na povezanost različitih aspekata intelektualnog funkcioniranja sa školskim ocjenama pokazala su da specifični oblici inteligencije imaju različit obrazac povezanosti s ocjenama iz pojedinih predmeta pri čemu tome uspjehu generalno najviše pridonose verbalne i numeričke te nešto manje apstraktne sposobnosti. Verbalne su se sposobnosti pokazale značajno povezane $\mathrm{s}$ uspjehom $\mathrm{u}$ predmetima jezično-komunikacijske skupine, za opći školski uspjeh i uspjeh u društveno-humanističkim područjima nužna je kombinacija verbalnih i numeričkih sposobnosti, pri čemu verbalne ipak imaju nešto važniju ulogu, dok su s uspjehom u prirodoslovno-matematičkoj skupini predmeta gotovo podjednako povezane sve tri skupine sposobnosti (Bennet, Seashore i Wesman, 2005). Osim za predikciju postignuća u svim razinama obrazovanja, ispitivanje kognitivnih sposobnosti pokazalo se korisnim i u predviđanju uspješnosti zaposlenih osoba, pogotovo kod poslova veće kompleksnosti (Kuncel, Ones i Sackett, 2010). Kako inteligencija prosječno objašnjava tek polovinu ukupne varijance školskog postignuća (Chamorro-Premuzic i Furnham, 2008), novija istraživanja usmjerila su se na 
otkrivanje faktora koji će dodatno doprinijeti objašnjenju varijance ovoga kriterija, među kojima je dio pažnje posvećen i crtama ličnosti i profesionalnim interesima.

Do boljeg razumijevanja važnosti obilježja ličnosti u objašnjenju školskog postignuća dolazi tek nakon elaboracije petofaktorske taksonomije, iako ne treba zanemariti ni ulogu Vrooma (1960), koji je znatno ranije isticao ulogu motivacije. Mada neki autori kao De Fruyt i Mervielde (1996) smatraju kako upravo petofaktorski model ličnosti najbolje objašnjava varijancu školskog postignuća, u prilog čemu idu i brojni longitudinalni i kroskulturalni nalazi (Rosander, 2012), određeni broj drugih autora drži da mjere inteligencije više predstavljaju indikator maksimalne izvedbe - onoga što je pojedinac sposoban učiniti, dok su crte ličnosti i profesionalni interesi viđeni kao indikatori tipične izvedbe ili onoga što bi pojedinac u stvarnosti uistinu uspio postići (Ciorbea i Pasarica, 2013). Drugim riječima, biti uspješan učenik ne znači samo proći ispit i ostvariti dobar uspjeh već moći pokazati svoje znanje na primjeren način, stvoriti i održati kvalitetan odnos s učiteljem i drugim učenicima u razredu te uključiti se u aktivnosti koje bi mogle zamijeniti one u kojima učenik pokazuje nisku izvedbu. Navedeno zapravo predstavlja praktičnu inteligenciju u školi koja se odnosi na razumijevanje i na sposobnost adekvatnog odgovora na zahtjeve školskog konteksta (Williams, Blythe, White, Gardner i Sternberg, 2002). Uobičajen je nalaz da crte ličnosti objašnjavaju $15 \%$ ukupne varijance školskih ocjena (Furnham i Monsen, 2009), no treba voditi računa i o tome da odnos crta ličnosti i izvedbe, odnosno školskog uspjeha i postignuća nije stabilan. Murphy (1989) tako navodi kako je na samom početku izvedbe važna kognitivna sposobnost pojedinca dok usavršavanje izvedbe zahtjeva aktivaciju motivacijskih procesa. Također, novija istraživanja, uz standardnih pet faktora, nastoje obuhvatiti i njihove facete čime je moguće objasniti i specifičnija ponašanja učenika (Paunonen i Ashton, 2013). Uzimajući u obzir odnos pojedinačnih crta sa školskim postignućem, istraživanja konzistentno upućuju na savjesnost kao značajan pozitivan prediktor (O'Connor i Paunonen, 2007; Vedel, 2014), dok rezultati za ekstraverziju, otvorenost za iskustva, neuroticizam i ugodnost nisu posve jednoznačni (Martin, Montgomery i Saphian, 2006). Ekstraverzija i ugodnost se npr. pokazuju pozitivno povezane sa školskim uspjehom na nižim, ali ne i na višim stupnjevima obrazovanja (Furnham, Chamorro-Premuzic i McDougall, 2003; Laidra i sur., 2007; Martin i sur., 2006). Neuroticizam se u nekim istraživanjima povezuje sa slabijom akademskom izvedbom (Mitrofan i Ion, 2013), neka pokazuju da je ta povezanost neznačajna (Furnham i Monsen, 2009), dok noviji rezultati idu u prilog zaključku da manja razina neuroticizma pridonosi motivaciji i uspješnosti učenika (Vedel, 2014). Slična se nekonzistentnost dobiva i za crtu otvorenosti za iskustva, gdje neki nalaze da je taj odnos pozitivan i značajan (Komarraju, Ramsey i Rinella, 2013; Noftle i Robins, 2007), dok se kod drugih ta veza ne dobiva (Chamorro-Premuzic i Furnham, 2003).

Profesionalni interesi, koje Holland (1997) definira složenim orijentacijama pojedinca povezanim s njegovom spremnošću da se uključi u neke od šest temeljnih tipova aktivnosti - realistične, istraživačke, umjetničke, socijalne, poduzetničke i 
konvencionalne, također se smatraju obilježjima povezanim sa školskim uspjehom. Ljudi uobičajeno imaju različito izražene preferencije prema svakom od navedenih Hollandovih tipova aktivnosti, prestavljajući tako jedinstvenu, samo za njega karakterističnu kombinaciju ili profil (Spokane i Cruza-Guet, 2005). Prema Hollandovoj teoriji kongruentnosti (1997) ljudi su uspješniji u onim područjima za koja imaju izraženije interese, pa je za očekivati i da će biti efikasniji u školskim predmetima čiji se sadržaji preklapaju s područjem koje ih zanima. Interesi učenika, posebice njihova stabilnost u vremenu, od osobite su važnosti za pojedinca jer čine preduvjet njegova odabira za daljnje školovanje, a naposljetku i odabira zanimanja kao odrasle osobe (Greenhaus, 2003). Rana su istraživanja odnosa interesa i školskog postignuća pokazala kako se njihova prosječna korelacija kreće oko .30 (Denissen, Zarrett i Eccles, 2007), a ovisi o spolu, dobi, razredu djeteta te školskom predmetu. Nalazi o povezanosti profesionalnih interesa s izvedbom u pojedinim domenama mogu se sumirati kroz rad Ackermana i Heggestada (1997), koji pokazuju da je izraženost istraživačkih interesa povezana $\mathrm{s}$ boljom izvedbom u spacijalnim, matematičkim, verbalnim i mehaničkim zadacima, realističnih $\mathrm{s}$ boljom izvedbom $\mathrm{u}$ spacijalnim, mehaničkim i matematičkim zadacima te umjetničkih s boljom izvedbom u verbalnim zadacima. Također, ovi autori nalaze da je izraženost konvencionalnih interesa povezana s boljim izvođenjem matematičkih zadataka, ali slabijim izvođenjem verbalnih, dok su viši socijalni i poduzetnički interesi povezani sa slabijom izvedbom u matematičkim i mehaničkim zadacima. Pored toga neka istraživanja pokazuju da su učenici s istraživačkim interesima uspješniji u školskim obavezama, dok oni s realističnim postižu uspjeh slabiji od prosjeka (Bloye, 2007). Vezano uz spol i dob rezultati ispitivanja interesa pokazuju da oni imaju veći utjecaj na ocjene dječaka nego djevojčica, a povezanost je, neovisno o spolu, snažnija u višim razredima (Krapp, 1999). S porastom dobi, naime, osobito nakon završetka puberteta, učenici se više identificiraju s odabranim područjem znanja i kompetencija te odbacuju druga, a učenje koncentrirano na usko odabrano područje posljedično dovodi i do višeg postignuća u njemu (Renninger, 2000).

Kako je očigledno, sposobnosti, crte ličnosti i profesionalni interesi konzistentno se u nalazima istraživača potvrđuju značajnim prediktorima školskog postignuća. Međutim, prema našim se saznanjima ulogom svih triju skupina varijabli istovremeno u predviđanju općega školskog uspjeha, kao i uspjeha u specifičnim skupinama predmeta, istraživači gotovo i nisu bavili. Stoga je cilj ovoga rada bio ispitati u kojoj mjeri različiti aspekti kognitivnog funkcioniranja - verbalno, numeričko i apstraktno - mogu predicirati opći školski uspjeh i uspjeh u pojedinim skupinama predmeta te utvrditi kakva je inkrementalna valjanost crta ličnosti povrh efekata sposobnosti, odnosno inkrementalna valjanost profesionalnih interesa povrh efekata sposobnosti i ličnosti za navedene kriterijske varijable.

$\mathrm{Na}$ temelju rezultata dosadašnjih nalaza, osobito onih Benneta i suradnika (2005), Chamorro-Premuzica i Furnhama (2003, 2008), O'Connora i Paunonena (2007) te Bloyea (2007), moguće je postaviti nekoliko hipoteza: 
H1. Verbalne, numeričke i apstraktne sposobnosti bit će značajni prediktori općega školskog postignuća kao i postignuća u prirodoslovno-matematičkoj i društveno-humanističkoj skupini predmeta, dok se kod ostalih skupina predmeta kao značajan prediktor očekuju uglavnom verbalne sposobnosti.

H2. Crte ličnosti značajno će predicirati opći školski uspjeh i uspjeh u svim specifičnim skupinama predmeta, a njihov doprinos bit će značajan i kada se isključe efekti sposobnosti na kriterijske varijable. Pri tome će najznačajniji biti doprinos dimenzije savjesnosti, koja će se pokazati značajnim samostalnim prediktorom uspješnosti svih mjerenih kriterija, dok bi se efekti ugodnosti mogli očekivati kod tehničke i umjetničke skupine predmeta.

H3. Profesionalni interesi značajno će predicirati sve mjerene kriterije školskog postignuća, pri čemu se može očekivati da će inkrementalnu valjanost povrh sposobnosti i crta ličnosti ostvariti jedino istraživački interesi.

\section{Metoda}

\section{Ispitanici}

Ispitivanje je provedeno na uzorku od 263 učenika (135 muškog i 128 ženskog spola) osmih razreda Osnovne škole "Vladimir Gortan" u Rijeci, s rasponom dobi od 13 do 14 godina koji su u razdoblju od posljednjih 5 godina pripadali generacijama završnih razreda.

\section{Mjerni instrumenti}

Za procjenu su intelektualnog funkcioniranja korištena tri subtesta DAT baterije (Diferencijalni testovi sposobnosti za učenike osnovnih škola; Bennett, Seashore i Wesman, 2006): Test verbalnog rasuđivanja, koji mjeri sposobnost razumijevanja odnosa među riječima, Test numeričkog rasuđivanja, koji mjeri sposobnost rješavanja matematičkih zadataka, odnosno matematičko rasuđivanje te Test apstraktnog rasuđivanja, koji predstavlja neverbalnu mjeru rasuđivanja. Ukupan se rezultat ispitanika na svakom testu dobiva zbrajanjem točnih rješenja. Navedene mjere predstavljaju hrvatsku inačicu originalnih subtestova (Differential Aptitude Tests; Bennett, Seashore i Wesman, 1974; prema Matešić, Jutriša i Pinjušić, 2005) i imaju zadovoljavajuće psihometrijske karakteristike. Na američkom i britanskom uzorku učenika koeficijenti unutarnje konzistencije (Cronbach alpha) su visoki i kreću se u rasponu od .79 do .94 (Bennett i sur., 2005; Hyde i Trickey, 2005), dok u ovom istraživanju iznose .69 za verbalno, .85 za neverbalno i .84 za apstraktno rasuđivanje. Korelacije među različitim DAT testovima na američkom i britanskom uzorku ispitanika kreću se od .68 ( $p<.01$, verbalno i neverbalno) do .70 ( $p<.01$, neverbalno i apstraktno rasuđivanje), dok su u ovom istraživanju u rasponu od .47 
( $p<.01$, verbalno i apstraktno rasuđivanje) do .54 ( $p<.01$, numeričko i apstraktno rasuđivanje). Spolne su razlike dobivene jedino na testu numeričkog rasuđivanja $(t=2.01, p<.05, d=.25)$, na kojem dječaci postižu statistički značajno više rezultate od djevojčica. Deskriptivni podaci i koeficijenti pouzdanosti za sve tri mjere sposobnosti kao i za druge mjere korištene u ovom radu prikazani su u Tablici 1 .

Za mjerenje dimenzija ličnosti korišten je Petofaktorski upitnik (Big Five Inventory, BFI; Benet-Martinez i John, 1998), kojim se kroz 44 čestice mjeri izraženost ekstraverzije, ugodnosti, savjesnosti, neuroticizma i otvorenosti za iskustva. Zadatak je ispitanika da koristeći Likertovu skalu od 5 stupnjeva procijene u kojoj se mjeri svaka tvrdnja odnosi na njih (1 -uopće se ne slažem; 5 - u potpunosti se slažem), a ukupan se rezultat ispitanika za svaku dimenziju dobiva zbrajanjem procjena na česticama koje ih sačinjavaju. Prema dosadašnjim je rezultatima istraživanja ovaj upitnik zadovoljavajućih psiholometrijskih karakteristika. Koeficijenti unutarnje konzistencije (Cronbach alpha) obično se kreću od .75 do .90 , $\mathrm{s}$ prosjekom većim od .80 , test-retest pouzdanosti u razmaku od 3 mjeseca iznose $\mathrm{u}$ prosjeku .85, a upitnik ima i visoku konvergentnu valjanost (Benet-Martinez i John, 1998). Struktura je ovoga upitnika na hrvatskom jeziku provjerena korištenjem konfirmatorne faktorske analize, a dobiveni indeksi pogodnosti upućuju na zadovoljavajuću prikladnost predviđene petofaktorske strukture (Kardum, Gračanin i Hudek-Knežević, 2006). Pouzdanosti unutarnje konzistencije (Cronbach alpha) na ovom uzorku ispitanika kreću se od .72 za ugodnost do .82 za savjesnost, a korelacije među dimenzijama od -.38 ( $p<.001$, ugodnost i neuroticizam) do .25 ( $p<.001$, ekstraverzija i otvorenost). Spolne su razlike dobivene na dimenziji neuroticizma $(t=2.63, p<.01, d=.32)$ i otvorenosti $(t=4.45, p<.001, d=.54)$, na kojima djevojčice postižu statistički značajno više rezultate od dječaka.

Vokacijski su interesi mjereni Upitnikom za samoprocjenu profesionalnih interesa (USPI, Šverko i Babarović, 2006), koji predstavlja hrvatsku inačicu Hollandova upitnika profesionalnih interesa (Holland, 1994a, 1994b, 1994c). Upitnik se sastoji od 228 čestica, odnosno po 38 za svaki pojedini tip interesa unutar RIASEC profila - Realistične, Istraživačke, Umjetničke, Socijalne, Poduzetničke i Konvencionalne, a sklonost pojedinim skupinama poslova mjeri se kroz četiri različite domene - aktivnosti, kompetencije, zanimanja i samoprocjene. Svoje preferencije prema različitim radnim aktivnostima i kompetencije za pojedine radne aktivnosti i zanimanja ispitanici procjenjuju na dihotomnim skalama (npr. "sviđa mi se", "ne sviđa mi se"), dok osobne sposobnosti i vještine procjenjuju na skali Likertova tipa od 7 stupnjeva (1 - moje sposobnosti/vještine su niske, 7 - moje sposobnosti/vještine su visoke). Ukupan rezultat ispitanika za svaki tip interesa formira se zbrajanjem odgovora na česticama koje ga sačinjavaju. Skale imaju zadovoljavajuću pouzdanost i valjanost (Holland, 1997; Šverko i Babarović, 2006), pri čemu se pouzdanosti unutarnje konzistencije (Cronbach alpha) na ovom uzorku ispitanika kreću od .83 za realistične do .92 za istraživačke interese. Korelacije među dimenzijama u ovom istraživanju kreću se od .01 ( $p>.05$, realistični i socijalni interesi) do .66 ( $p<.01$, poduzetnički i konvencionalni interesi). Spolne su razlike 
dobivene kod realističnih i poduzetničkih interesa gdje dječaci postižu veće vrijednosti (realistični $t=9.72, p<.001, d=1.20$; poduzetnički $t=3.55, p<.001, d=.44$ ) te kod umjetničkih i socijalnih interesa gdje veće vrijednosti postižu djevojčice (umjetnički $t=7.40, p<.001, d=.91$; socijalni $t=5.26, p<.001, d=.65$ ).

Upitnikom općih podataka $i$ školskog postignuća prikupljeni su opći podaci o učenicima, podaci o njihovu općem školskom postignuću na kraju sedmog razreda i postignuću u pojedinačnim predmetima, a ovi su podaci naknadno provjereni uvidom u školsku dokumentaciju. Ukupna prosječna ocjena na kraju školske godine korištena je kao mjera općeg školskog postignuća, a pored nje korištene su ocjene iz pojedinačnih predmeta koje su za potrebe ovog istraživanja svrstane u specifične skupine prema klasifikaciji školskih predmeta Ministarstva znanosti, obrazovanja i sporta (2011). Tako su jezično-komunikacijskom skupinom obuhvaćeni hrvatski te prvi i drugi strani jezik, u ovom slučaju engleski i talijanski; prirodoslovnom skupinom biologija, kemija, fizika i matematika, društveno-humanističkom skupinom povijest, geografija i vjeronauk; tehničkom tehnička kultura; dok su se u umjetničkoj skupini našli glazbena i likovna kultura.

\section{Postupak}

Za sudjelovanje je u istraživanju tražen pristanak roditelja, koji su bili obaviješteni o njegovim ciljevima i mjerama koje će se koristiti. Učenici i roditelji dodatno su motivirani naknadnim predavanjem i savjetovanjem o izboru zanimanja i srednjoškolskog obrazovanja. Odaziv je vjerojatno zbog toga bio vrlo velik, odnosno tek oko $2 \%$ djece nije sudjelovalo u ispitivanju. Cjelokupan instrumentarij primjenili su studenti psihologije $u$ jednom navratu, dijelom u terminu školske nastave, a dijelom izvan njega, a ispitivanje je trajalo oko 3 sata. Instrumentarij je uključivao tri subtesta DAT baterije (Test verbalnog rasuđivanja, Test numeričkog rasuđivanja i Test apstraktnog rasuđivanja) namijenjenih mjerenju specifičnih sposobnosti, Petofaktorski upitnik namijenjen mjerenju dimenzija ličnosti, Upitnik za samoprocjenu profesionalnih interesa te Opći upitnik kojim su prikupljeni opći podaci kao i podaci o školskim ocjenama.

\section{Rezultati}

Deskriptivni statistički parametri svih korištenih mjera te njihove interkorelacije prikazani su u Tablici 1 . Rezultati povezanosti među prediktorskim varijablama inteligencijom, crtama ličnosti i profesionalnim interesima pokazuju sljedeće: verbalno i numeričko rezoniranje značajno su pozitivno povezani s ekstraverzijom, savjesnošću i istraživačkim profesionalnim interesima, a numeričko je rezoniranje pored toga značajno pozitivno povezano i $\mathrm{s}$ poduzetničkim profesionalnim interesima te negativno s dimenzijom neuroticizma. Apstraktno je rezoniranje značajno pozitivno povezano samo $\mathrm{s}$ istraživačkim profesionalnim interesima. 
Ekstraverzija je značajno pozitivno povezana sa socijalnim i poduzetničkim interesima, savjesnost s istraživačkim, socijalnim i poduzetničkim, otvorenost za iskustva $\mathrm{s}$ istraživačkim, umjetničkim i socijalnim, dok je ugodnost značajno negativno povezana s realističnim i poduzetničkim interesima.

Iz prikaza korelacija među kriterijskim varijablama vidljivo je da su one sve međusobno statistički značajno umjereno do visoko pozitivno povezane, a kreću se od .45 za povezanost uspjeha u tehničkoj i uspjeha u umjetničkoj skupini predmeta do .95 za povezanost između općega školskog uspjeha u sedmom razredu i uspjeha u jezično-komunikacijskoj skupini predmeta.

Koeficijenti korelacije između prediktorskih i kriterijskih varijabli pokazuju da su sve sposobnosti statistički značajno pozitivno povezane sa svim mjerama školskog postignuća, odnosno da su od svih prediktorskih varijabli one s njima gotovo najviše povezane. Veze verbalnog rezoniranja s kriterijima kreću se od .25 (uspjeh u tehničkoj skupini) do .50 (uspjeh u prirodoslovnoj skupini), numeričkog i kriterija između .17 (uspjeh u umjetničkoj skupini) i .51 (uspjeh u prirodoslovnoj skupini predmeta), dok se veze apstraktnog rezoniranja s kriterijskim varijablama kreću od .14 (uspjeh u tehničkoj skupini) do .49 (uspjeh u prirodoslovnoj skupini).

Od crta ličnosti najvišu vezu s kriterijskim varijablama ostvaruje dimenzija savjesnosti. Ona je, naime, statistički značajno pozitivno povezana sa svim mjerenim ishodima pri čemu je ta povezanost najniža $\mathrm{s}$ uspjehom u umjetničkoj skupini predmeta (.18), a najviša $\mathrm{s}$ uspjehom u prirodoslovnoj skupini predmeta (.30). Dimenzija ekstraverzija povezana je značajno pozitivno sa svim ishodima osim $\mathrm{s}$ uspjehom u tehničkoj i umjetničkoj skupini predmeta, a njezine su veze znatno slabije i kreću se od $.13 \mathrm{~s}$ uspjehom u prirodoslovnoj skupini do $.16 \mathrm{~s}$ uspjehom $\mathrm{u}$ jezično-komunikacijskoj skupini, dok ugodnost i otvorenost za iskustva ostvaruju samo po jednu značajnu vezu i to obje s uspjehom u umjetničkoj skupini predmeta (ugodnost od .18, a otvorenost od .23).

Od profesionalnih interesa najvišu vezu sa školskim postignućem ostvaruju istraživački profesionalni interesi, koji su značajno pozitivno povezani sa svim mjerenim kriterijima, pri čemu se te vrijednosti kreću od .20 za uspjeh u tehničkoj skupini predmeta do .50 za uspjeh u prirodoslovnoj skupini predmeta. Značajne pozitivne, iako nešto slabije veze s kriterijima ostvaruju i socijalni interesi, a one se kreću od .13 s uspjehom u prirodoslovnoj skupini do $.20 \mathrm{~s}$ uspjehom u jezičnokomunikacijskoj skupini, pri čemu ovi interesi uopće nemaju značajnu vezu s uspjehom u tehničkoj skupini. Ostale značajne veze profesionalnih interesa s kriterijima relativno su niske. Tako su poduzetnički interesi povezani značajno pozitivno s općim uspjehom, uspjehom u prirodoslovnoj-skupini i uspjehom u društveno-humanističkoj skupini (korelacije se kreću od .13 do .16), umjetnički interesi značajno su pozitivno povezani $\mathrm{s}$ uspjehom u jezično komunikacijskoj skupini i uspjehom u umjetničkoj skupini (korelacije iznose .14 i .18), dok realistični interesi ostvaruju samo jednu i to negativnu vezu od -.17 s uspjehom u jezičnokomunikacijskoj skupni predmeta. Konvencionalni interesi nisu značajno povezani s uspjehom ni u jednoj skupini kriterijskih varijabli. 


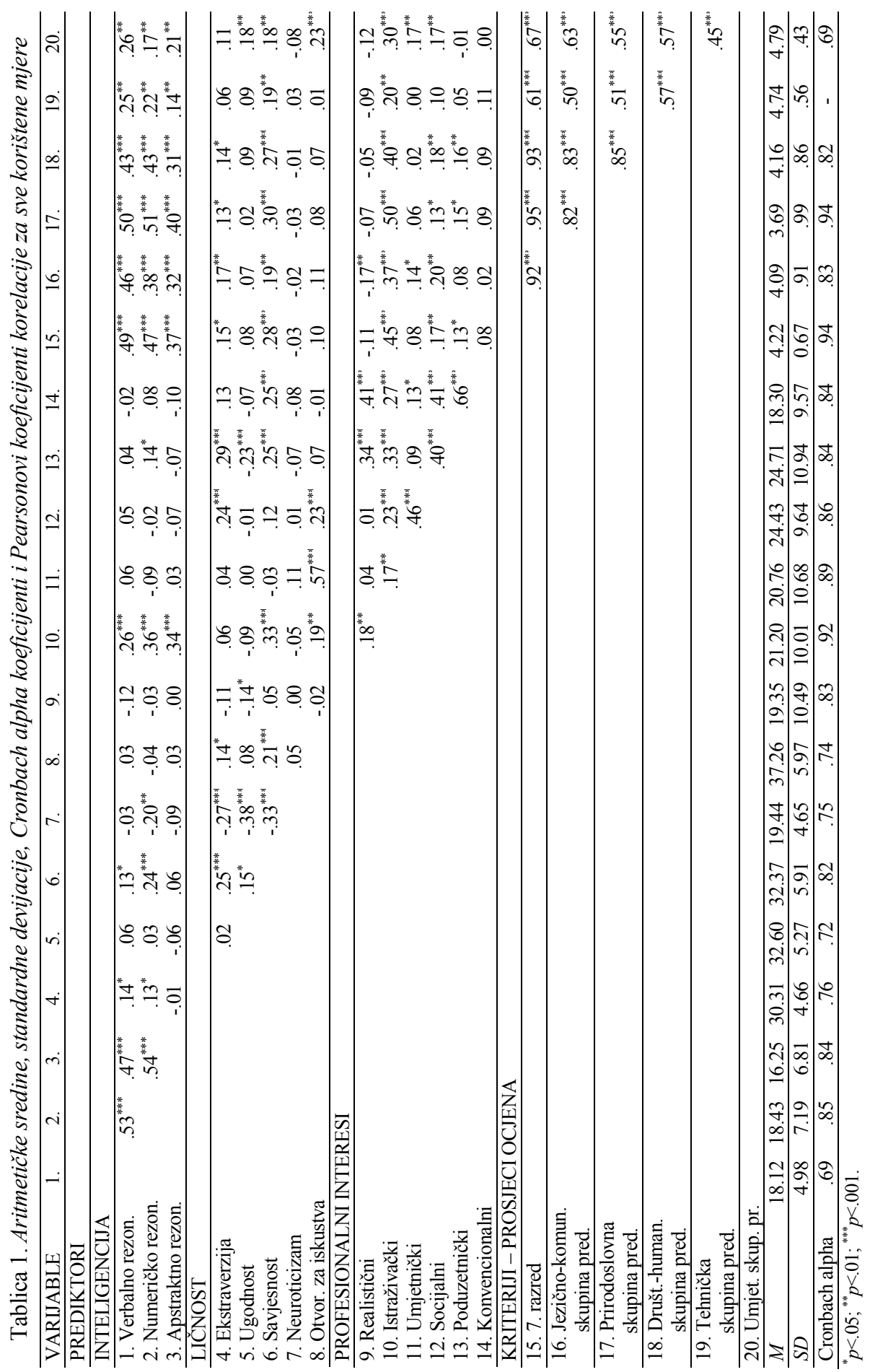


Kako bi se ispitalo u kojoj mjeri sposobnosti, crte ličnosti i profesionalni interesi predviđaju opći uspjeh učenika na kraju sedmog razreda te uspjeh u specifičnim skupinama predmeta - jezično-komunikacijskoj, prirodoslovnoj, društvenohumanističkoj, tehničkoj i umjetničkoj skupini, proveden je niz hijerarhijskih regresijskih analiza. Kao prediktorske varijable u prvom su koraku uključene verbalne, numeričke i apstraktne sposobnosti, u drugom koraku uključene su crte ličnosti petofaktorskog modela - ekstraverzija, ugodnost, savjesnost, neuroticizam i otvorenost za iskustva, a u trećem Hollandovi profesionalni interesi - realistični, istraživački, umjetnički, poduzetnički, socijalni i konvencionalni. Dobiveni su rezultati hijerarhijskih regresijskih analiza prikazani u Tablici 2., gdje su navedeni beta-koeficijenti iz zadnjeg koraka hijerarhijske regresijske analize.

Tablica 2. Rezultati hijerarhijskih regresijskih analiza s općim školskim uspjehom i uspjehom u specifičnim skupinama predmeta kao kriterijskim varijablama

\begin{tabular}{|c|c|c|c|c|c|c|}
\hline \multirow[b]{2}{*}{ PREDIKTORI } & \multicolumn{6}{|c|}{ KRITERIJI } \\
\hline & $\begin{array}{l}\text { Opći } \\
\text { školski } \\
\text { uspjeh }\end{array}$ & $\begin{array}{l}\text { Uspjeh u jez.- } \\
\text { komunikac. } \\
\text { skupini pred. }\end{array}$ & $\begin{array}{c}\text { Uspjeh u } \\
\text { prirodosl. } \\
\text { skupini pred. }\end{array}$ & $\begin{array}{c}\text { Uspjeh u } \\
\text { društ.-human. } \\
\text { skupini pred. }\end{array}$ & $\begin{array}{l}\text { Uspjeh u } \\
\text { tehničkoj } \\
\text { skupini } \\
\text { pred. }\end{array}$ & $\begin{array}{l}\text { Uspjeh u } \\
\text { umjetničkoj } \\
\text { skupini } \\
\text { pred. }\end{array}$ \\
\hline \multicolumn{7}{|l|}{ INTELIGENCIJA } \\
\hline Verbalno rasuđivanje & $.26^{* * *}$ & $.27^{* * *}$ & $.24^{* * *}$ & $.23^{* *}$ & $.20^{* *}$ & $.17^{*}$ \\
\hline Numeričko rasuđivanje & $.20^{* *}$ & .14 & $.24^{* * *}$ & $.20^{* *}$ & $.18^{*}$ & -.01 \\
\hline Apstraktno rasuđivanje & .07 & .06 & .07 & .06 & -.03 & .06 \\
\hline$R^{2}$ & $.32^{* * * *}$ & $.26^{* * * *}$ & $.35^{* * * *}$ & $.26^{* * *}$ & $.13^{\text {**** }}$ & $.09^{* * * *}$ \\
\hline \multicolumn{7}{|l|}{ CRTE LIČNOSTI } \\
\hline Ekstraverzija & .04 & .09 & .03 & .04 & .01 & .04 \\
\hline Ugodnost & .11 & .09 & .05 & $.14^{*}$ & .10 & $.16^{*}$ \\
\hline Savjesnost & $.13^{*}$ & .06 & $.14^{*}$ & $.13^{*}$ & .13 & .05 \\
\hline Neuroticizam & $.14^{*}$ & .10 & $.12^{*}$ & $.17^{* *}$ & $.16^{*}$ & .01 \\
\hline Otvorenost & -.03 & -.05 & -.04 & -.02 & -.04 & .12 \\
\hline$R^{2}$ & $.37^{* * * *}$ & $.29^{* * *}$ & $.40^{* * *}$ & $.31^{* * *}$ & $.17^{* * * *}$ & $.17^{* * *}$ \\
\hline$\Delta R$ & $.05^{* * *}$ & $.03^{*}$ & $.05^{* *}$ & $.05^{* *}$ & .04 & $.08^{* * * *}$ \\
\hline \multicolumn{7}{|c|}{ PROFESIONALNI INTERESI } \\
\hline Realistični interesi & -.09 & $-.14^{*}$ & -.09 & -.03 & -.09 & -.07 \\
\hline Istraživački interesi & $.26^{* * * *}$ & $.22^{* *}$ & $.29^{* * *}$ & $.20^{* *}$ & .04 & $.21^{* *}$ \\
\hline Umjetnički interesi & .00 & .08 & .01 & -.08 & -.03 & .03 \\
\hline Socijalni interesi & .09 & .11 & .03 & $.14^{*}$ & .06 & .10 \\
\hline Poduzetnički interesi & .02 & .01 & .02 & .06 & -.07 & -.07 \\
\hline Konvencionalni interesi & -.03 & -.07 & -.01 & -.06 & .13 & -.03 \\
\hline$R^{2}$ & $.44^{* * *}$ & $.36^{* * *}$ & $.47^{* * *}$ & $.37^{* * * *}$ & $.18^{* * *}$ & $.22^{* * * *}$ \\
\hline$\Delta R$ & $.07^{* * * *}$ & $.07^{* * * *}$ & $.07^{* * * *}$ & $.06^{* *}$ & .01 & $.05^{*}$ \\
\hline
\end{tabular}

$" p<.05 ; " * p<.01 ; " * n<.001$

Kako je vidljivo iz Tablice 2., značajni prediktori općega školskog uspjeha u sedmom razredu su inteligencija, crte ličnosti i profesionalni interesi. Inteligencija objašnjava $32 \%$ varijance kriterija pri čemu se kao značajni samostalni prediktori pokazuju verbalno i numeričko rezoniranje. Crte ličnosti povrh sposobnosti značajno objašnjavaju dodatno još $5 \%$ varijance kriterija, a kao samostalni prediktori javljaju 
se savjesnost i neuroticizam, pri čemu je javljanje neuroticizma kao prediktora posljedica supresorskog efekta crta ugodnosti i savjesnosti. Profesonalni interesi također se pokazuju važnim prediktorom koji objašnjava značajno povrh efekata sposobnosti i crta ličnosti još $7 \%$ varijance kriterija, pri čemu su samo istraživački interesi značajan samostalan prediktor.

Inteligencija, crte ličnosti i profesionalni interesi pokazali su se značajnim pozitivnim prediktorima uspjeha i kod svih ostalih kriterija, odnosno kod svih mjerenih skupina predmeta, pri čemu i crte ličnosti i interesi dodatno značajno objašnjavaju varijancu kriterija povrh varijabli uključenih u prethodnim koracima regresijeke analize. Značajnu inkrementalnu valjanost crte ličnosti i profesionalni interesi ne pokazuju jedino kod uspjeha u tehničkoj skupini predmeta.

Inteligencija tako objašnjava $26 \%$ varijance uspješnosti $u$ jezičnokomunikacijskoj skupini predmeta pri čemu se kao značajni samostalni prediktor javlja verbalno rezoniranje. Crte ličnosti povrh sposobnosti značajno objašnjavaju dodatno još $3 \%$, a profesionalni interesi povrh efekata sposobnosti i crta ličnosti još $7 \%$ varijance kriterija, pri čemu su istraživački i realistični interesi značajni samostalni prediktori.

Kada se radi o uspjehu u prirodoslovnoj skupini predmeta, inteligencija objašnjava $35 \%$ varijance kriterija pri čemu su značajni samostalni prediktori verbalno i numeričko rezoniranje. Crte ličnosti povrh sposobnosti značajno objašnjavaju dodatno još $5 \%$ varijance kriterija, a kao samostalni prediktori javljaju se savjesnost i neuroticizam koji se i ovdje javio kao prediktor usljed supresorskog efekta crta ugodnosti i savjesnosti. Važnim se prediktorom pokazuju i profesonalni interesi koji objašnjavaju značajno povrh efekata sposobnosti i crta ličnosti još $7 \%$ varijance kriterija, a među njima se kao značajan samostalan prediktor javljaju samo istraživački interesi.

Kod društveno-humanističke skupine predmeta inteligencija objašnjava $26 \%$ varijance kriterija pri čemu su značajni samostalni prediktori verbalno i numeričko rezoniranje. Crte ličnosti povrh sposobnosti značajno objašnjavaju dodatno još 5\% varijance kriterija, a kao samostalni se prediktori javljaju savjesnost, ugodnost i neuroticizam pri čemu su se i ugodnost i neuroticizam javile kao posljedica supresorskog efekta. Važnim se prediktorom pokazuju i profesonalni interesi, koji objašnjavaju značajno povrh efekata sposobnosti i crta ličnosti još $6 \%$ varijance kriterija, a među njima se kao značajani samostalni prediktor javljaju istraživački i socijalni interesi.

Inteligencija je značajan prediktor uspjeha i u tehničkoj skupini predmeta, međutim ona objašnjava samo $13 \%$ varijance ovog kriterija, a značajni su samostalni prediktori verbalno i numeričko rezoniranje. Iako su se pored nje i crte ličnosti i profesionalni interesi također pokazali kao značajni prediktori, oni u ovom slučaju povrh varijabli uključenih u prethodni korak ne pridonose značajno objašnjenju varijance kriterija. Pored toga treba navesti i da je javljanje neuroticizma kao 
samostalnog prediktora i ovdje posljedica supresorskog efekta crta ugodnosti i savjesnosti.

Kod uspjeha u umjetničkoj skupini inteligencija objašnjava tek $9 \%$ varijance kriterija, a samostalnim se prediktorom pokazalo samo verbalno rezoniranje. Crte ličnosti povrh sposobnosti značajno objašnjavaju dodatno još $8 \%$ varijance kriterija, pri čemu se kao samostalan prediktor javlja dimenzija ugodnosti, dok profesonalni interesi povrh sposobnosti i crta ličnosti objašnjavaju dodatno još $5 \%$ varijance kriterija, pri čemu su samo istraživački interesi značajan samostalni prediktor.

Kada se izmjeni redosljed varijabli u posljednja dva koraka hijerarhijskih regresijskih analiza, odnosno u drugom uključe profesionalni interesi, a u trećem crte ličnosti, rezultati pokazuju da interesi u drugom koraku povrh inteligencije uglavnom objašnjavaju veću količinu varijance kriterija no što je to bio slučaj s crtama ličnosti. Interesi u drugom koraku povrh inteligencije objašnjavaju 9\% varijance općega školskog uspjeha, 9\% varijance uspjeha u jezično-komunikacijskoj skupini predmeta te $10 \%$ varijance uspjeha u prirodoslovnoj skupini predmeta, što je više nego što to $\mathrm{u}$ istom koraku ostvaruju crte ličnosti. Kod ostalih kriterijskih varijabli razlika u doprinosu crta ličnosti i profesionalnih interesa s obzirom na redosljed uključivanja nije toliko izražena.

\section{Rasprava}

Cilj je ovoga rada bio ispitati u kojoj mjeri inteligencija, crte ličnosti i profesionalni interesi pridonose objašnjenju varijance općega školskog postignuća učenika osnovne škole te postignuća u specifičnim skupinama predmeta: jezičnokomunikacijskoj, prirodoslovnoj, društveno-humanističkoj, tehničkoj i umjetničkoj. Također, nastojalo se utvrditi i koliki je doprinos crta ličnosti povrh efekata sposobnosti, odnosno koliki je doprinos profesionalnih interesa povrh efekata sposobnosti i crta ličnosti.

Dobiveni su rezultati pokazali da su sposobnosti najznačajniji prediktor kako općeg školskog uspjeha, tako i uspjeha u specifičnim skupinama predmeta. Sposobnosti pri tome najviše pridonose objašnjenju varijance uspjeha $u$ prirodoslovnoj skupini (35\%), potom objašnjenju varijance općega školskog uspjeha (32\%), uspjeha u jezično-komunikacijskoj i društveno-humanističkoj skupini (po $26 \%$ ), dok je njihov doprinos najmanji u objašnjenju varijance uspjeha u tehničkoj (13\%) i umjetničkoj skupini predmeta (9\%). Kod uspjeha u jezično-komunikacijskoj i umjetničkoj skupini kao samostalan se prediktor javlja samo verbalno rezoniranje, dok se kod svih ostalih kriterija kao samostalni prediktori javljaju i verbalno i numeričko rezoniranje. Pri tome je doprinos verbalnog rezoniranja najčešće nešto veći od numeričkog osim kod uspjeha u prirodoslovnoj skupini predmeta, gdje je taj doprinos podjednak. Ovi su rezultati u skladu s dosadašnjima, koji nedvosmisleno pokazuju da je inteligencija najbolji prediktor uspjeha u školi. Naime, već Jensen 
(1980) navodi da ona objašnjava između $35 \%$ i $60 \%$ varijance školskog postignuća, a slične nalaze potvrđuju i brojni drugi autori (De Fruyt, Van Leeuwen, De Bolle i De Clercq, 2008; Donodova i Donodov, 2012). Pri tome su, kao i u ovom istraživanju, sa školskim uspjehom najviše povezane verbalne i numeričke sposobnosti, dok je povezanost ocjena $\mathrm{s}$ apstraktnim rezoniranjem nešto slabija (Bennet i sur., 2005). Korelacije dobivene ovim radom slične su i s nalazima standardizacije DAT baterije na britanskom uzorku (vidi Bennet i sur., 2005), koji također pokazuju da su verbalne i numeričke sposobnosti značajno povezane kako s općim školskim uspjehom, tako s uspjehom u specifičnim skupinama predmeta. Kako je evidentno i iz njihovih nalaza, verbalne su sposobnosti najbolji prediktor uspjeha u jezično-komunikacijskoj skupini, kombinacija verbalnih i numeričkih najbolji je prediktor općega školskog uspjeha i uspjeha u društveno-humanističkim područjima, pri čemu verbalne imaju nešto važniju ulogu, dok su za uspjeh u prirodoslovno-matematičkoj skupini obje sposobnosti gotovo podjednako važne. Iako su i na britanskom i na uzorku ovog istraživanja apstraktne sposobnosti također značajno povezane sa školskim uspjehom, ta je povezanost znatno manja od one koju ostvaruju verbalne i numeričke sposobnosti, a u ovom radu one se nisu istaknule kao prediktor nijednog od mjerenih kriterija. Pored ovih nalaza treba istaknuti da su, osim sa školskim uspjehom, istraživači potvrdili značaj općega kogntivnog funkcioniranja i za predviđanje uspjeha u procesima osposobljavanja i radnom izvođenju, a rezultati su metaanalitičkih studija pokazali da se njegova povezanost s kriterijem uspjeha u procesu osposobljavanja kreće između .53 (Hunter i Hunter, 1984; Schmidt i Hunter, 1998) i .67 (Levin, Spector, Menon, Narayanon i Cannon-Bowers, 1996), dok povezanost $\mathrm{s}$ radnom učinkovitošću iznosi oko .50 (Schmidt i Hunter, 1998). Važnost i način utjecaja verbalnih sposobnosti za uspjeh u školskom postignuću već je dobro elaboriran od strane brojnih autora (Chamorro-Premuzic i Furnham, 2004, 2005; Flanagan, Andrews i Genshaft, 1997), a ogleda se kroz brže i bolje razumijevanje gradiva, kao i kroz bolju kvalitetu usmene i pismene forme izražavanja naučenog, djelujući na taj način na uspjeh u gotovo svim školskim zadacima u kojima se barata s tekstom. S druge strane, numeričko rezoniranje koje mjeri sposobnost rješavanja matematičkih zadataka važno je najviše za prirodoslovno-matematičke predmete zbog svoje sličnosti sa zadacima te skupine predmeta, ali je zbog toga što na neki način predstavlja opću sposobnost rješavanja problemskih zadataka povezano i s uspjehom u društveno-humanističkoj skupini predmeta kao i s općim uspjehom. Iz dobivenih je nalaza moguće zaključiti da je prediktivnost sposobnosti za uspjeh u osnovnoj školi nešto manja od one prosječne koja se dobivala u ranijim nalazima. Ovakav rezultat može upućivati na to da su se navike učenja ponešto promijenile, odnosno da je činjenica o nezaposlenosti između $20 \%$ i 30\% mladih u velikom broju europskih zemalja, a u Hrvatskoj čak i preko $40 \%$, povećala pritisak zbog kojega intenzivnije učenje današnji osnovnoškolci i njihovi roditelji drže važnim alatom u borbi za buduće zaposlenje. Zbog toga je distribucija ocjena vjerojatno uža nego ranije, a same ocjene manje diskriminativne. 
Što se tiče doprinosa crta ličnosti u objašnjenju različitih kriterija uspjeha u osnovnoj školi, naši rezultati pokazuju da i one razmatrane kao skup varijabli predstavljaju značajan prediktor i to povrh efekata sposobnosti. Crte u ovom istraživanju u prosjeku dodatno objašnjavaju još oko $5 \%$ varijance kriterija, pri čemu se kao najvažniji samostalni prediktor ističe jedino savjesnost, dok je ugodnost samostalan prediktor samo uspjeha u umjetničkoj skupini predmeta. Na važnost savjesnosti za postignuće u obrazovnom procesu upućuju i nalazi drugih autora (Bratko, Chamorro-Premuzic i Furnham, 2006; Sacket, Gruys i Ellingson, 1998), a korelacija ove crte s postignućem kreće se od .16 do .44 ovisno o načinu mjerenja ličnosti, predmetima i uzrastu učenika (De Fruyt i sur., 2008). Uloga je savjesnosti očekivana jer osobe s visokim rezultatom na ovoj skali teže postignuću, od sebe zahtijevaju izvrsnost, iznimno su samodisciplinirane i sklone napornom radu (Mount, Barick i Straus, 1999; Noftle i Robins, 2007; Rosander, 2012), što im osigurava bolji uspjeh u gotovo svim aktivnostima, a neki autori nalaze da se u pozadini veze savjesnosti i školskog postignuća nalazi učenikova orijentacija usmjerena cilju koja djeluje kao medijator (Sorić, Penezić i Burić, 2017). Osim u školi, ova se crta pokazala izvrsnim prediktorom i u radnom okruženju. Rezultati metaanalize Barricka i Mounta (1991) npr. pokazuju da ona dobro predicira širok raspon kriterija vezanih uz posao, da njezina prediktivna valjanost za predviđanje stupnja izvođenja iznosi preko .20 te da je to jedina dimenzija ličnosti čija je prediktivna valjanost generalizirana kroz različite poslove i uvjete. Neka su istraživanja pokazala da su $\mathrm{s}$ boljim uspjehom u osnovnoj školi povezane i esktraverzija i ugodnost kao i da se njihov utjecaj sa starošću postupno smanjuje, pa ti efekti u srednjoj školi više nisu vidljivi (Laidra i sur., 2007; Martin i sur., 2006). U našem je istraživanju od ovih rezultata potvrđen jedino efekt ugodnosti, i to samo kod uspjeha u umjetničkoj skupini predmeta, pa je realno pretpostaviti da se unutar ove nastave, pored sposobnosti učenika za umjetničko izražavanje, vrednuju i njegova spremnost za kooperaciju, briga i lijepo ponašanje.

Profesionalni interesi uključeni $\mathrm{u}$ trećem koraku hijerahijskih regresijskih analiza dodatno su pridonijeli objašnjenju varijance i općega školskog postignuća i postignuća u svim spefičnim skupinama predmeta osim u tehničkoj. Pri tome prosječna količina objašnjene varijance iznosi oko 6\%, a kao značajan samostalan prediktor pokazali su se jedino istraživački interesi. I dok se prema Hollandovoj teoriji kongruentnosti veći uspjeh u pojedinim skupinama aktivnosti može očekivati na temelju sukladnosti pojedinčevih interesa sa zadacima te domene, očigledno je da su za predikciju boljega školskog postignuća u sedmom razredu najvažniji istraživački interesi. Ovakav je nalaz dijelom logičan s obzirom na to da istraživački interesi podrazumijevaju usmjerenost na nova znanja, potrebu za shvaćanjem pojava koje nas okružuju, želju za novim iskustvima i idejama, što je kompatibilno s obavezama školskog programa. S druge strane, moglo bi se očekivati da će se i neki drugi interesi pokazati značajnima za uspjeh u određenim skupinama predmeta kao npr. realistični za tehničku skupinu ili socijalni za jezično-komunikacijsku i društveno-humanističku, no to ovim istraživanjem ipak nije dobiveno. Iako se spolno 
specifični interesi počinju javljati već vrlo rano, oko treće godine, stabilniji se vokacijski interesi mogu očekivati tek oko četrnaeste godine (Wigfield i Cambria, 2010) te je moguće da zbog toga na našem uzorku nisu dobiveni navedeni rezultati. Realistični interesi, naime, nisu se pokazali značajno povezani $\mathrm{s}$ uspjehom u tehničkoj skupini predmeta vjerojatno stoga što se nedostatak ovih interesa u osnovnoj školi još uvijek može kompenzirati intenzivnijim učenjem gradiva, dok su socijalni interesi značajno povezani s uspjehom u gotovo svim skupinama, no ta veza nije još dovoljno jaka da bi se ovi interesi pokazali značajnim prediktorom. Vezano uz doprinos profesionalnih interesa u objašnjenju školskog postignuća treba također napomenuti i da su rezultati ovog istraživanja pokazali kako oni povrh efekata inteligencije objašnjavaju veću količinu varijance općega školskog postignuća, postignuća u jezično-komunikacijskog te u prirodoslovnoj skupini nego što je to slučaj s crtama ličnosti.

Na kraju možemo zaključiti da je ovaj rad jedan od rijetkih koji ispituje istovremeni doprinos inteligencije, crta ličnosti i profesionalnih interesa školskoj uspješnosti učenika. Pri tome dobiveni rezultati potvrđuju neke dosadašnje spoznaje kao npr. da je za uspjeh u osnovnoj školi najvažnije dobro verbalno i numeričko rezoniranje, da je verbalno rezoniranje općenito nešto značajnije kako za opći, tako i za uspjeh u većini pojedinačnih skupina predmeta, dok je za dobre rezultate $u$ prirodoslovo-matematičkoj skupini važnost verbalnog i matematičkog rezoniranja gotovo podjednaka. Povrh toga, pokazalo se da uz sposobnosti boljem uspjehu značajno pridonose i crte ličnosti i profesionalni interesi, osobito visoka savjesnost i sklonost istraživačkim aktivnostima koji dodatno, povrh sposobnosti, objašnjavaju u prosjeku još oko $11 \%$ varijance mjerenih kriterija. Dobiveni nalazi upućuju na važnost ispitivanih varijabli u razumijevanju i predviđanju osnovnoškolskog postignuća kao i na moguće intervencije koje bi mogle osigurati s jedne strane bolju prilagodbu školskih programa karakteristikama učenika, a s druge učenika programskim sadržajima. Jedna bi od intervencija mogla biti npr. i poticanje razvoja istraživačkih aktivnosti i interesa već kod učenika mlađe dobi, što je danas prilično zapostavljeno jer u obrazovnom sustavu središnje mjesto imaju usvajanje i reprodukcija velike količine gradiva.

Buduća bi istraživanja usmjerena ispitivanju ove problematike trebala koristiti veće i reprezentativnije uzorke škola te ispitanike različitih dobnih skupina čime bi se omogućila bolja generalizacija rezultata. Također, poboljšanja nacrta mogla bi se osigurati i uključivanjem faceta temeljnih crta ličnosti petofaktorskog modela čime bi se mogli dobiti precizniji odgovori o ulozi pojedinih dimenzija u školskom postignuću učenika različite dobi. 


\section{Literatura}

Ackerman, P.L. i Heggestad, E.D. (1997). Intelligence, personality, and interests: Evidence for overlapping traits. Psychological Bulletin, 121, 219-245.

Babarović, T., Burušić, J. i Šakić, M. (2010). Psihosocijalne i obrazovne odrednice školskog uspjeha učenika osnovnih škola: Dosezi dosadašnjih istraživanja. Suvremena psihologija, 13, 235-256.

Barrick, M.R. i Mount, M.K. (1991). The Big Five personality dimensions and job performance: A metaanalysis. Personnel Psychology, 44, 1-26.

Benet-Martinez, V. i John, O.P. (1998). Los Cincos Grandes across cultures and ethnic groups: Multitrait multimethod analyses of the Big Five in Spanish and English. Journal of Personality and Social Psychology, 75, 729-750.

Bennett, G.K., Seashore, H.G. i Wesman, A.G. (2006). DAT za profesionalno usmjeravanje i selekciju: Priručnik za Diferencijalne testove sposobnosti. Jastrebarsko: Naklada Slap.

Bloye, E.J. (2007). Vocational interests and other non-cognitive factors as predictors of academic performance in high school. Magistarski rad. Johannesburg: University of Johannesburg.

Bratko, D., Chamorro-Premuzic, T. i Furnham, A. (2006). Personality and school performance: Incremental validity of self- and peer-ratings over intelligence. Personality and Individual Differences, 41, 131-142.

Chamorro-Premuzic, T. i Furnham, A. (2003). Personality predicts academic performance: Evidence from two longitudinal university samples. Journal of Research in Personality, 37, 319-338.

Chamorro-Premuzic, T. i Furnham, A. (2004). A possible model for understanding the personality-intelligence interface. British Journal of Psychology, 95, 249-264.

Chamorro-Premuzic, T. i Furnham, A. (2005). Personality and intellectual competence. New Jersey: Lawrence Erlbaum Associates, Inc.

Chamorro-Premuzic, T. i Furnham, A. (2008). Personality, intelligence and approaches to learning as predictors of academic performance. Personality and Individual Differences, 44, 1596-1603.

Ciorbea, I. i Pasarica, F. (2013). The study of the relationship between personality and academic performance. Procedia - Social and Behavioral Sciences, 78, 400-404.

De Fruyt, F. i Mervielde, I. (1996). Personality and interests as predictors of educational streaming and achievement. European Journal of Personality, 10, 405-425.

De Fruyt, F., Van Leeuwen, K., De Bolle, M. i De Clerq, B. (2008). Sex differences in school performance as a function of conscientiousness, imagination and the mediating role of problem behaviour. European Journal of Personality, 22, 167-184.

Denissen, J.J.A., Zarrett, N.R. i Eccles, J.S. (2007). I like to do it, I'm able, and I know I am: Longitudinal couplings between domain-specific achievement, self-concept, and interest. Child Development, 78, 430-447. 
Dodonova, Y.A. i Dodonov, Y.S. (2012). Processing speed and intelligence as predictors of school achievement: Mediation or unique contribution? Intelligence, 40, 163-171.

Flanagan, D.P., Andrews, T.J. i Genshaft, J.L. (1997). The functional utility of intelligence tests with special education populations. U: D.P. Flanagan, J.L. Genshaft i P.L. Harrison (Ur.), Contemporary intellectual assessment: Theories, tests, and issues (str. 457-483). New York, NY: Guilford.

Furnham, A., Chamorro-Premuzic, T. i McDougall, F. (2003). Personality, cognitive ability, and beliefs about intelligence as predictors of academic performance. Learning and Individual Differences, 14, 49-66.

Furnham, A. i Monsen, J. (2009). Personality traits and intelligence predict academic school grades. Learning and Individual Differences, 19, 28-33.

Greenhaus, J.H. (2003). Career Dynamics. U: I.B. Weiner (Ur.), Handbook of psychology: Volume 12 - Industrial and organizational psychology (str. 519-540). New Jersey: John Wiley \& Sons, Inc.

Holland, J.L. (1994a). Self-directed search: Assessment booklet, a guide to educational and career planning. Odessa, FL: Psychological Assessment Resources, Inc.

Holland, J.L. (1994b). Self-directed search: The occupations finder. Odessa, FL: Psychological Assessment Resources, Inc.

Holland, J.L. (1994c). Self-directed search: You and your career. Odessa, FL: Psychological Assessment Resources, Inc.

Holland, J.L. (1997). Making vocational choices: A theory of personalities and work environments. Odessa: Psychological Assessment Resources.

Hyde, G. i Trickey, G. (2005). Priručnik diferencijalnih sposobnosti; DAT za profesionalno usmjeravanje i selekciju. Jastrebarsko: Naklada Slap.

Hunter, J.E. i Hunter, R.F. (1984). Validity and utility of alternate predictors of job performance. Psychological Bulletin, 96, 72-98.

Jensen, A.R. (1980). Uses of sibling data in educational and psychological research. American Educational Research Journal, 17, 153-170.

Kardum, I., Gračanin, A. i Hudek-Knežević, J. (2006). Odnos crta ličnosti i stilova privrženosti s različitim aspektima seksualnosti kod žena i muškaraca. Psihologijske teme, 15, 101-128.

Krapp, A. (1999). Interest, motivation and learning: An educational-psychological perspective. European Journal of Psychology of Education, 14, 23-40.

Komarraju, M., Ramsey, A. i Rinella, V. (2013). Cognitive and non-cognitive predictors of college readiness and performance: Role of academic discipline. Learning and Individual Differences, 24, 103-109.

Kuncel, N.R., Ones, D.S. i Sackett, P.R. (2010). Individual differences as predictors of work, educational, and broad life outcomes. Personality and Individual Differences, 49, 331-336. 
Laidra, K., Pullmann, H. i Allik, J. (2007). Personality and intelligence as predictors of academic achievement: A cross-sectional study from elementary to secondary school. Personality and Individual Differences, 42, 441-451.

Levine, E.L., Spector, P.E., Menon, P.E., Narayanon, L. i Cannon-Bowers, J. (1996). Validity generalization for cognitive, psychomotor, and perceptual tests for craft jobs in the utility industry. Human Performance, 9, 1-22.

Matešić, K., Jutriša, D. i Pinjušić, K. (2005). Hrvatska standardizacija DAT-a za profesionalno usmjeravanje i selekciju. U: G.K. Bennett, H.G. Seashore i A.G. Wesman (Ur.), DAT za selekciju baterija tehničkih sposobnosti: Priručnik za diferencijalne testove sposobnosti: Hrvatska standardizacija europske adaptacije 5. izdanja DAT baterije (str. 109-120). Jastrebarsko: Naklada Slap.

Martin, J.H., Montgomery, R.L. i Saphian, D. (2006). Personality, achievement test scores, and high school percentile as predictors of academic performance across four years of coursework. Journal of Research in Personality, 40, 424-431.

Mitrofan, N. i Ion, A. (2013). Predictors of academic performance: The relation between the Big Five factors and academic performance. Procedia - Social and Behavioral Sciences, $78,125-129$.

Ministarstvo znanosti, obrazovanja i športa RH (2011). Nacionalni okvirni kurikulum za predškolski odgoj i obrazovanje te opće obvezno i srednjoškolsko obrazovanje. Zagreb: Ministarstvo znanosti, obrazovanja i športa RH.

Mount, M.K., Barrick, M.R. i Strauss, J.P. (1999). The joint relationship of conscientiousness and ability with performance: Test of the interaction hypothesis. Journal of Management, 25, 707-721.

Murphy, K.R. (1989). Is the relationship between cognitive ability and performance stable over time? Human Performance, 2, 183-200.

Noftle, E.E. i Robins, R.W. (2007). Personality predictors of academic outcomes: Big Five correlates of GPA and SAT scores. Journal of Personality and Social Psychology, 93, 116-130.

O'Connor, M.C. i Paunonen, S.V. (2007). Big Five personality predictors of post-secondary academic performance. Personality and Individual Differences, 43, 971-990.

Paunonen, S.V. i Ashton, M.C. (2013). On the prediction of academic performance with personality traits: A replication study. Journal of Research in Personality, 47, 778-781.

Petska, K.S. (2006). Using personality variables to predict academic success in personalized system of instruction. Preuzeto s http://digitalcommons.unl.edu/cehsdiss/3

Renninger, K.A. (2000). Individual interest and its implications for understanding intrinsic motivation. U: C. Sansone i J.M. Harackiewicz (Ur.), Intrinsic and extrinsic motivation: The search for optimal motivation and performance (str. 373-404). San Diego: Academic Press.

Rosander, P. (2012). The importance of personality, IQ and learning approaches: Predicting academic performance. Lund: Media Tryck. 
Sackett, P.R., Gruys, H.L. i Ellingson, J.E. (1998). Ability-personality interactions when predicting job performance. Journal of Applied Psychology, 83, 545-556.

Schmidt, F.L. i Hunter, J.E. (1998). The validity and utility of selection methods in personnel psychology: Practical and theoretical implications of 85 years of research findings. Psychological Bulletin, 124, 262-274.

Sorić, I., Penezić, Z. i Burić, I. (2017). The Big Five personality traits, goal orientations, and academic achievement. Learning and Individual Differences, 54, 126-134.

Spokane, A.R. i Cruza-Guet, N.C. (2005). Holland's Theory of vocational personalities in work environments. U: S.D. Brown i R.W. Lent (Ur.), Career development and counseling: Putting theory and research to work (str. 24-41). New Jersey: John Wiley $\&$ Sons, Inc.

Šverko, I. i Babarović, T. (2006). The validity of Holland's theory in Croatia. Journal of Career Assessment, 14, 490-507.

Vedel, A. (2014). The Big Five and tertiary academic performance: A systematic review and meta-analysis. Personality and Individual Differences, 71, 66-76.

Vroom, V. (1960). The effects of attitudes on perception of organizational goals. Human Relations, 13, 229-240.

Wigfield, A. i Cambria, J. (2010). Students' achievement values, goal orientations, and interest: Definitions, development, and relations to achievement outcomes. Developmental Review, 30, 1-35.

Williams, W.M., Blythe, T., White, N., Gardner, H. i Sternberg, R.J. (2002). Practical intelligence for school: Developing metacognitive sources of achievement in adolescence. Developmental Review, 22, 162-210.

\title{
Intelligence, Personality Traits and Vocational Interests as Predictors of School Achievement
}

\begin{abstract}
The aim of this study was to explore the extent to which intelligence, personality traits, and vocational interests are related to the general school achievement of elementary school children as well as to achievement in a specific group of school subjects (verbal-communicational, scientific, social-humanistic, technical and artistic group). Additionally, we also examined incremental validity of personality traits and vocational interests over and above the effects of intelligence. The research was carried out on 263 eight grade children (128 males and 135 females) from one elementary school. In order to investigate a predictive strength of intelligence, personality traits, and vocational interests in predicting general and school achievements in the specific group of school subjects, several hierarchical regression analysis were performed, in which personality traits were included in the first, intelligence in the second, and vocational interests in the third step of analysis.
\end{abstract}


The results obtained show that verbal, numeric and abstract abilities, as well as conscientiousness and investigative interests, are strongest predictors of general school achievement and achievement in most specific groups of school subjects, explaining between $9 \%$ and $35 \%$ variance. Moreover, results show that personality traits over the effects of abilities and vocational interests over the effects of abilities and personality traits explain an additional proportion of variance of all criteria variables, except achievement in the technical group of subjects. Personality traits and vocational interests together explain about $11 \%$ variance of criteria (personality 5\%; vocational interests $6 \%$ ). The research results highlight the importance of intelligence, personality traits and vocational interests for understanding and predicting achievement in elementary school.

Keywords: intelligence, personality traits, vocational interests, school achievement

\section{Inteligencia, rasgos de personalidad e intereses profesionales como predictores del logro escolar}

\section{Resumen}

El objetivo de este trabajo fue examinar hasta qué medida la inteligencia, los rasgos de personalidad y los intereses profesionales contribuyen a la explicación de la varianza del logro escolar general de los alumnos que frecuentan clases superiores de colegio, tanto como sus logros en grupos específicos de materias (lingüístico-comunicativo, de ciencias naturales, social-humanístico, técnico y artístico). Además, se ha examinado e incrementado la validez de los rasgos de personalidad e intereses profesionales, además de los efectos de capacidad. En la investigación participaron 263 alumnos que frecuentan la octava clase de un colegio en Rijeka (Croacia), de los que 128 son chicas y 135 chicos. Para examinar la fuerza predictiva de la inteligencia, los rasgos de personalidad y los intereses profesionales como predictores del logro escolar general y en cada uno de los grupos de materias específicas como variables criterio, se ha llevado a cabo una serie de análisis de regresión jerárquica en los que se ha incluido la inteligencia en el primer paso, los rasgos de personalidad en el segundo y los intereses personales en el tercero. Los resultados obtenidos muestran que los predictores más importantes del logro escolar general y aquel en la mayoría de los grupos específicos de materias son las capacidades verbales y numéricas, intereses en investigación y escrupulosidad, con la varianza explicada de entre $9 \%$ y $35 \%$. Además, se ha demostrado que los rasgos de personalidad más que la inteligencia, e intereses profesionales más que la intelegencia y los rasgos de personalidad, contribuyen significativamente a la explicación de la varianza de todas las variables criterio, menos el logro en el grupo técnico de materias. Las dimensiones de personalidad e intereses juntos explican un promedio de $11 \%$ de varianza de criterio (personalidad 5\%, intereses profesionales 6\%). Los resultados obtenidos indican la importancia de las variables examinadas para entender y predecir el logro escolar en el colegio.

Palabras claves: inteligencia, rasgos de personalidad, intereses profesionales, logro escolar

Primljeno: 10.02.2017. 